\title{
WHAT FACTORS INFLUENCE THE CAREER CHOICE OF HOTEL MANAGEMENT MAJOR STUDENTS IN GUANGZHOU?
}

\author{
Shaoping Qiu \\ Texas A\&M University, USA \\ E-mail: qsp680504@tamu.edu \\ Larry Dooley \\ Texas A\&M University, USA \\ E-mail: I-dooley@tamu.edu \\ Trupti Palkar \\ Texas A\&M University, USA \\ E-mail: trupsworld@tamu.edu
}

Submission: $23 / 01 / 2017$

Revision: 06/02/2017

Accept: 20/02/2017

\section{ABSTRACT}

The purpose of this paper is to investigate the students' perceptions of importance with reference to influencing factors of their career options in the Hospitality Department of a polytechnic college in Guangzhou City, China. A convenience sampling technique was adopted in this study. The study result was derived from a survey of 372 students. The questionnaire comprised items relating to factors influencing students when they made their career decision. Descriptive statistics, T-test, and a factor analysis were conducted using SPSS 21.0. It was discovered that more students made their own career choice with less influence from traditional values and family members. It was also shown there was generally no statistically significant difference between male and female students; however, a difference between freshmen and sophomore respondents was found for some items. Additionally, this study identified five underlying contributory factors. "Students self-efficacy and occupational aspiration" was the most important factor to 
INDEPENDENT JOURNAL OF MANAGEMENT \& PRODUCTION (IJM\&P)

http://www.ijmp.jor.br

V. 8, n. 3, July - September 2017

ISSN: 2236-269X

DOI: 10.14807/ijmp.v8i3.618

influence the students' career decision, followed by "tradition and cultural value", "career guidance", "support from parents", and "external consultation". Finally, discussion of the findings and limitations of this study were presented and possible suggestions were given for both hospitality educators and professionals.

Keywords: career choice, hospitality management students, Guangzhou

\section{INTRODUCTION}

China has experienced vigorous economic expansion and prosperity for more than four decades. Tourism, as one of the most important industry in China, has enjoyed tremendous growth and maintained a sound momentum of steady development. In 2015, it was reported China's tourism witnessed a steady increase with a total of 133.8204 million inbound tourists by the end of that year (CHINA INBOUND TOURISM in 2015, 2015). The fast growing tourism market has galvanized hotel development (OKOROAFO; KOH; LIU; JIN, 2010). Most recent statistics showed China had 11,180 star-rated hotels; business revenue of star-rated hotels amounted to CNY 215 billion (CHINA TOURISM FACTS \& FIGURES 2014, n.d.).

Guangzhou, due to its close proximity to Hong Kong, and with a population of more than 17 million people, has spearheaded China's economy since the 1980s. This city has always remained a magnet for hotel companies. In addition, serving as the host of Asian games further stimulated the expansion of hotel industry development. There were reportedly 216 star hotels in Guangzhou in 2015 (ZHAO, 2015). However, growth opportunities for the hotel industry have given rise to numerous issues, the most critical of which is the shortage of human resources in hotel workforce.

Obviously, more star hotels require more qualified employees to perform hotel jobs. However, as the hotel industry grows steadily, the problem of high turnover rates persists. Anecdotal evidence suggests turnover among hotel employees could be as high as 40 percent per year in China (WOLFINGTON; WOLFINGTON, 2012).

It stands to reason that Guangzhou is no exception. In order to gain competitive advantage, hotels in this city have come to realize it is of uttermost priority to establish a sound human resources strategy. It is critical to attract and retain large numbers of qualified employees to ensure their success in the fiercely 
competing industry.

Traditionally, there have been many channels for hotels to recruit prospective employees. Hotel and tourism management (HTM) undergraduate students are believed to be the best source due to student quality and quantity. Although students are virtually considered as talent reservoir for hotels at the time they matriculate into HTM program, unfortunately, most of these students show no interest to stay in this service industry after graduation (WONG; LIU, 2010).

Only a small percentage of HTM graduate students elect to find employment in hotels; it is interesting to note a large percentage of these working graduates choose to leave for jobs in other industries shortly after working in hotels. Therefore, it is paramount to address this aspect of human resource challenges in order to help hotels in Guangzhou to attract and retain qualified HTM graduates.

\section{PURPOSE OF THE STUDY}

Both the hotel industry and HTM institutions would suffer if HTM students show reluctance to work in the hotel industry. For this reason, it is important to identify the reasons behind this phenomenon and take some countermeasures to deal with the issue theoretically and practically.

Although ample studies have examined the factors affecting students' career choice decision-making in the USA and many other countries, there is a scarcity of research specifically exploring the contributing factors associated with career choice of Chinese HTM undergraduate students, much less the studies targeting HTM students in Guangzhou city.

The purpose of this study was to identify the factors which influence the career choice of HTM major undergraduates in Guangzhou, and to examine how these contributing factors affect students' decision-making for their career. This study also made some suggestions and recommendations for HTM educators and hotel industry managers.

\section{CONCEPTUAL UNDERPININGS}

Comprehensive understanding of how HTM undergraduate students make decisions in choosing their future careers entails going back to basic career development (CD) theories. Therefore, instead of reviewing literature closely related 
INDEPENDENT JOURNAL OF MANAGEMENT \& PRODUCTION (IJM\&P)

http://www.ijmp.jor.br

V. 8, n. 3, July - September 2017

ISSN: 2236-269X

DOI: 10.14807/ijmp.v8i3.618

to HTM students' career choice, we first review career development theories that could be most appropriate to function as a conceptual framework to guide this exploratory study.

There are voluminous articles focusing generally on career choice and development for young people. From the CD extant related literature, Super's Lifespan, Life-space Theory (SUPER, 1990; SUPER; SAVICKAS; SUPER, 1996) and Social Cognitive Career Theory (SCCT) (LENT, 2005; LENT; BROWN; HACKETT, 2002) have been most relevantly used to guide the career choice and development practice and research in the past few decades. These two theories also served as an overarching framework to guide our study.

\subsection{Super's Life-span, Life-space Theory}

This leading career developmental approach was credited to Donald Super (1990) who recognizes the career development as a lifelong process. According to Super (1990), career patterns are determined by socioeconomic factors, cultures, abilities, personalities, values, self-concepts, and the opportunities to which people are exposed.

Career choice and development is essentially a process through which people can express themselves, implement and develop their self-concepts, and ultimately obtain the career satisfaction through work roles. Life span, life space, career maturity, self-concept are the most highlighted constructs in Super's theory.

Super (1990) suggests a series of developmental stages and tasks are typically encountered during an individual's life span: growth (childhood), exploration (adolescence), establishment (early adulthood), and maintenance (middle adulthood), as well as disengagement (late adulthood).

Super (1990) further proposes that a mini-cycle including the same stages from growth to disengagement would likely occur within each of the stages, particularly when a person makes a transition from one stage to the next. Moreover, a mini-cycle of the stages would be experienced by adolescents whenever they have to make expected or unexpected career transitions such as loss of job or due to personal or socioeconomic circumstances (SAVICKAS, 2002).

Another essential construct is self-concept which Super (1963) defines as a "picture of the self in some role, situation, or position, performing some set of 
INDEPENDENT JOURNAL OF MANAGEMENT \& PRODUCTION (IJM\&P)

http://www.ijmp.jor.br

v. 8, n. 3, July - September 2017

ISSN: 2236-269X

DOI: 10.14807/ijmp.v8i3.618

functions, or in some web of relationships" (p.18). Later, Super (1990) expands this meaning and postulated that self-concept is a product of complex interactions among a number of factors, including physical and mental growth, personal experiences, and environmental characteristics and stimulation.

Self-concept is formed through social, experiential, interactive learning, and reflective self-awareness. An individual possesses both objective and subjective selfconcept to identify appropriate career goals. Objectively, self-understanding could be built by comparing one's self with others. However subjectively speaking, people develop understanding through focusing on their uniqueness emerging out of their life stories (NILES; HARRIS-BOWLSBEY, 2005).

\subsection{Social Cognitive Career Theory}

Social cognitive career theory (SCCT) (LENT, 2005; LENT et al., 2002) is considered relevant theory to understand the factors influencing students' career choice in this study. SCCT emphasizes the cognitive-person constructs, such as self-efficacy, outcome expectations, and personal goals, and highlights how these constructs interact with personal inputs (e.g., gender, ethnicity, ability and personality ) and contextual factors (e.g., family, culture, gender-role socialization) to help shape the course of career development

Self-efficacy is referred to as "a dynamic set of beliefs that are linked to particular performance domains and activities" (LENT, 2005, p. 104). According to SCCT, feelings of self-efficacy are emanated from four sources of information: (a) Mastery experiences: personal performance and accomplishments; (b) Verbal persuasion: feedback from important others on one's interests and abilities; (c) Vicarious experience; and (d) Physiological responses: states such as anxiety, composure, and exhilaration, and overall affective reactions of liking or disliking something. Self-efficacy is a predictor of career choice (BANDURA, 1986).

Outcome expectations are defined as personal beliefs about the outcomes of performing a specific behavior (LENT et al., 2002). According to Leung (2008), outcome expectations are formed by the same information or learning experiences shaping self-efficacy beliefs. They consist of beliefs about extrinsic reward related to performing the target behavior, self-directed consequences, and task performance outcome. This factor affects choice goal behavior and therefore is also a determinant 
when individuals make a career decision (LENT et al., 2002).

Personal goals refer to the determination to engage in a particular activity or to bring about a particular outcome (LENT et al., 2002). Setting goals is critical for persons in their career development in that goals function to organize and guide behavior, sustain it over long periods of time, and increase the likelihood that longterm goals will be reached.

Contextual supports and barriers are also important to understand the careerrelated choice behavior among undergraduate students. Lent, Brown and Hackett (2000) categorize contextual cognitive factors into either distal supports and barriers or proximal supports and barriers to career choices. They go on to elucidate how undergraduate students are supposed to be surrounded by their immediate environment influencing this choice, comprising friendships, financial situation, and parental influence when they encounter career choice.

To reiterate, it is deemed most relevant to use the CD theories aforementioned to examine the contributory factors influencing students' career choice making. Notwithstanding, it should be noted that Super's theory and SCCT are fundamentally derived from a USA context, reflecting a European-American perspective.

The applicability of career choice and development to specific discipline requires a set of theoretical frameworks with global validity and credibility, as well as culture-specific models that could be used to explain career development issues and phenomenon at a local level. The next section will be devoted to research method and examination of the factors that influence the HTM major students' career choice.

\section{RESEARCH QUESTIONS}

Based on the purpose of this study, we propose the following research questions:

a) Are there differences between students' gender in terms of constructs concerning students' career choice?

b) Are there differences between students' grades in terms of constructs concerning students' career choice?

c) What are the main factors influencing career choice of HTM students in 
DOI: 10.14807/ijmp.v8i3.618

\section{Guangzhou?}

\section{RESEARCH METHODOLOGY}

The instrument for this research was a self-administered questionnaire that sought to probe the reasons why the student respondents chose a career in the hospitality industry. Drawing on theoretical frameworks described above and related studies conducted by Borchert (2002), Bui (2005), Chuang \& Dellmann-Jenkins (2010), Tay (1996), Wong and Liu (2010), and Zahari (2004), along with the researchers' own observations and interactions with the students, we identified a list of thirty-four items to describe the factors influencing students' career choice.

The questionnaire comprised two sections. The first asked the student respondents to rate the degree of their attitudes (agree or disagree) towards the items. For all scales in this section, a five-point Likert-type scale was adopted where "five" represented the highest level of agreement, while "1" anchored at "strongly disagree". The second section sought to elicit socio-demographic data about student respondents, such as gender, grade, age, and length of former experience in hospitality industry.

\subsection{Data Collection}

The survey of this research was undertaken in the Tourism Department at a polytechnic college in Guangzhou. The questionnaires were distributed to hospitality major freshman and sophomore students. The respondents were asked to return the questionnaires immediately upon completion.

\subsection{The Sample}

A convenience sampling technique was adopted for this study, and surveys were administered to 383 freshman and sophomore students majoring in hospitality. Participants were told their participation in the study was voluntary. Among the 383 questionnaires collected, 11 surveys had missing information and thus were discarded from further analysis, generating a usable response rate of $97.1 \%$. Of the total of 372 usable respondents, 292 were females (78.5\%) and 80 males (21.5\%). With regards to age, since the sample is all Chinese first and second-year college students whose age fell between 18 to 21 years-old, it was not used as an independent variable in this study. Instead, it was deemed more appropriate to use the grade of the sample. It was found the freshman and sophomore students were 
almost evenly distributed with each numbering 193 (51.9\%) and 179 (48.1\%) respectively. 281 respondents $(75.5 \%)$ reported they had no experience in the hospitality industry, 84 students recorded themselves as having less than one year experience, whereas only $7(1.9 \%)$ categorized their experience as more than one year.

The demographic characteristics of the sample were checked with the Tourism Department of this polytechnic college, which indicated the profiles of our sample matched the official records of student information. Additionally, the mapping of the student residential locations developed by the Admission Department of this college showed the vast majority of students are originally from all parts of the Guangdong Province. Consequently, it could be possibly claimed that the sample is representative of Guangzhou's college students.

\subsection{Data Analysis}

Data collected was analyzed using the Statistical Package for the Social Sciences (SPSS) 21.0. First, simple descriptive statistics were derived for the respondents including frequency, percentage, means, and standard deviations for all items. Second, in order to ascertain if there were statistically significant difference between ages and grades, T- tests were applied to pinpoint the items that saliently existed differences. Lastly, factor analysis was conducted to extract the contributing factors that affected students' career choice.

\section{FINDINGS}

\subsection{Data Reliability}

Prior to undertaking further analysis of the data, statistical reliability scores were computed for the scale. The Cronbach's Alpha coefficient was 0.88 , while the split-half correlations were 0.80 . The Kaiser-Meyer-Olkin measures of sample adequacy were also calculated, with a value of 0.88 . All these scores excessed the cut-off rate of 0.70 recommended by Nunnally (1978), indicating internal rigor for further analysis.

\subsection{The Most Important Factors}

The first section of this survey dealt with the comparative importance of the listed 34 items. Table 1 and 2 indicated the most and least important contributory 
INDEPENDENT JOURNAL OF MANAGEMENT \& PRODUCTION (IJM\&P)

http://www.ijmp.jor.br

v. 8, n. 3, July - September 2017

ISSN: 2236-269X

DOI: 10.14807/ijmp.v8i3.618

factors influencing students' career choice by descending order of mean scores, respectively. It was found that the most important factors when making decisions about career choice were "making my own career choice" (3.94), "family support" (3.65), and "discussion of career choice with classmates" (3.62). "Aspiring to be a manager 5-10 years after graduation" was also thought important, with a mean score of 3.59, followed by "good relationship with hospitality industry" (3.51) and "respect of family wishes" (3.47).

With reference to the least important factors, "parents force me to follow their career choice they made" (1.91), "family business" (1.96), and "parents only support the decision about my future career that they want me to pursue" (2.23) were in the top three of this category. It was interesting to note that "traditional values" was considered to be the least important factor and scored low at a value of 2.42. It was noticeable that, for the items of "making my own career choice" and "discussion of career choice with classmates", the standard deviation were much lower than for many others, indicating that there was almost unanimous agreement with little extreme values on these items.

Table 1: The 11 Most Important Factors values on these items.

\begin{tabular}{|c|c|c|c|}
\hline Item & $\mathrm{N}$ & Mean & $\begin{array}{l}\text { Std. } \\
\text { Deviation }\end{array}$ \\
\hline 4. It is me who makes my career choice. & 372 & 3.9409 & .81875 \\
\hline 10. My family always supports my career decision & 372 & 3.6532 & .85980 \\
\hline 11. I often discuss my career choice with my classmates. & 372 & 3.6210 & .79343 \\
\hline 28. I aspire to become a manager five to ten years after graduation. & 372 & 3.5887 & .90829 \\
\hline $\begin{array}{l}\text { 24. I have and keep good personal relationships with people in } \\
\text { hospitality. }\end{array}$ & 372 & 3.5134 & .84505 \\
\hline $\begin{array}{l}\text { 8. When I made my career decision, I feel the need to respect my family } \\
\text { members' wishes as to what career would be best for me. }\end{array}$ & 372 & 3.4677 & .88200 \\
\hline 25. I know what abilities are required to be a good hospitality employee. & 372 & 3.4355 & .83626 \\
\hline 22. I enjoy working with different people. & 372 & 3.3710 & .94713 \\
\hline $\begin{array}{l}\text { 14. I used career reference books to know more about myself and the } \\
\text { hospitality jobs I wanted to pursue. }\end{array}$ & 372 & 3.3629 & .91999 \\
\hline 29. Working in hospitality industry can help me fulfill my self-actualization. & 372 & 3.3629 & .86565 \\
\hline $\begin{array}{l}\text { 7. When I make career choice, I asked instructors who had much } \\
\text { hospitality industry experience more than those who did not have. }\end{array}$ & 372 & 3.3441 & .95443 \\
\hline
\end{tabular}


INDEPENDENT JOURNAL OF MANAGEMENT \& PRODUCTION (IJM\&P)

http://www.ijmp.jor.br

v. 8, n. 3, July - September 2017

ISSN: 2236-269X

DOI: 10.14807/ijmp.v8i3.618

Table 2: The 6 Least Important Factors

\begin{tabular}{|l|r|r|r|}
\hline Item & $\mathrm{N}$ & Mean & \multicolumn{1}{c|}{$\begin{array}{c}\text { Std. } \\
\text { Deviation }\end{array}$} \\
\hline 20. People in hospitality industry influence me to choose hospitality jobs. & 372 & 2.4758 & .90340 \\
\hline 32. I chose hospitality major because of traditional values. & 372 & 2.4247 & .89155 \\
\hline $\begin{array}{l}\text { 17. My parents expect me to choose an occupation that is in line with the } \\
\text { family tradition. }\end{array}$ & 372 & 2.3118 & .91385 \\
\hline $\begin{array}{l}\text { 2. My parents only support the decision about my future career that they } \\
\text { want me to pursue. }\end{array}$ & 372 & 2.2285 & .91348 \\
\hline $\begin{array}{l}\text { 12. I choose to work in hospitality industry because of my family } \\
\text { business. }\end{array}$ & 372 & 1.9597 & .90282 \\
\hline $\begin{array}{l}\text { 3. My parents always force me to follow their career choice they made for } \\
\text { me. }\end{array}$ & 372 & 1.9140 & .85190 \\
\hline
\end{tabular}

\subsection{Gender and Grade Statistical Differences}

T-tests were adopted to examine the differences between genders. For the most part, there was no statistically significant difference between genders except for four items, namely, parents forcing students to follow their career choice, family business, running their own business, and parents only providing career information they wanted students to pursue. Here, male students tended to score these factors higher than their female counterparts. The largest mean differences between males and females were parents forcing students to follow their career choice (2.19 versus $1.84, p=0.001)$ and family business $(2.20$ versus $1.90, p=0.007)$. It can be noted that the respondents tended to express their disagreements with the two statements.

With reference to grades, it was found there were 14 items that showed a significant difference between freshman and sophomore respondents. As a whole, freshman respondents put more value on the scores of almost all items. First-year students rated the influence of teachers and counselors in their career choice at 3.06 $(p=0.000)$, while sophomores scored at $2.66(p=0.000)$. This meant students tended to value less the advice of teachers and counselors as they stayed longer in school.

Again, the group of freshmen felt the hospitality jobs more challenging and interesting than sophomores (3.45 versus $3.00, p=0.000)$. In addition, the first year respondents tended to over-estimate the value of working with different people and the role of the career reference book. However, there were a few items possessing minus difference, the most significant of which was the length of hospitality experience (2.46 versus $2.80, p=0.003)$. 


\subsection{Factor analysis}

To delineate the underlying constructs associated with influencing factors of career choice, principal component analysis was used, in this instance, a two-stage method was performed to extract common dimensions from the 34 variables. As mentioned above, Cronbach's Alpha coefficient and Kaiser-Meyer-Olkin measures of sample adequacy were both calculated as 0.88 , and Bartlett's test of sphericity was computed with a value of $3892.54, p<0.001$, implying that data were suitable for factor analysis.

The Scree Test indicated nine main dimensions all possess an eigenvalue in excess of 1.0. Therefore, a total of 34 items for factor analysis resulted in 9 main extracted dimensions. However, it was found there were a few dimensions comprising only one or two variables, and additionally, the factor loadings of a few variables were distributed almost evenly on some extracted dimensions.

These 10 variables involved were not deemed to be reliable and were therefore excluded from the further factor analysis. The results of the second stage factor analysis were presented in table 3 . This time, the remaining 24 items for factor analysis resulted in 5 main extracted dimensions accounting for $52.8 \%$ of explained variance. Each dimension was named based on the common characters of the items concerned.

(1) The first dimension was named "students self-efficacy and occupational aspiration", which accounted for $16.6 \%$ of the variance (alpha coefficient $=0.85$ ).

(2) The second was labeled "tradition and cultural value", which explained $11.9 \%$ of the total variance with an alpha coefficient of 0.72 .

(3) With a reliability alpha of 0.61 , the third dimension was "career guidance" which accounted for $8.5 \%$ of the total variance.

(4) The fourth, labeled "support from parents", had an alpha of 0.57 and accounted for $8.2 \%$ of the total variance.

(5) The last dimension was named "external consultation", explained $7.6 \%$ of the total variance. The alpha coefficient equaled 0.51 . 
Table 3: Factor Analysis of Influencing Factorsa

\begin{tabular}{|c|c|c|c|c|c|}
\hline & \multicolumn{5}{|c|}{ Dimension } \\
\hline & 1 & 2 & 3 & 4 & 5 \\
\hline $\begin{array}{l}\text { 28. I aspire to become a manager in hospitality industry five to ten years } \\
\text { after graduation. }\end{array}$ & .723 & & & & \\
\hline $\begin{array}{l}\text { 23. I think that I have the abilities to work well in hospitality and climb up } \\
\text { to higher position. }\end{array}$ & .705 & & & & \\
\hline 26. My personalities fit the hospitality jobs. & .671 & & & & \\
\hline $\begin{array}{l}\text { 29. Working in hospitality industry can help me fulfill my self- } \\
\text { actualization. }\end{array}$ & .647 & & & & \\
\hline $\begin{array}{l}\text { 33. I feel comfortable in hospitality industry which is characterized by } \\
\text { hierarchical structure. }\end{array}$ & .587 & & & & \\
\hline 27. High level managers in hospitality industry have high social status. & .570 & & & & \\
\hline $\begin{array}{l}\text { 34. I chose hospitality major because I like the atmosphere in hospitality } \\
\text { industry where both employees and staff are friendly to each other. }\end{array}$ & .544 & & & & \\
\hline $\begin{array}{l}\text { 24. I have and keep good personal relationships with people in } \\
\text { hospitality industry. }\end{array}$ & .527 & & & & \\
\hline 25. I know what abilities are required to be a good hospitality employee. & .526 & & & & \\
\hline 22. I enjoy working with different people in hospitality industry. & .501 & & & & \\
\hline 32. I chose hospitality major because of traditional values. & & .732 & & & \\
\hline $\begin{array}{l}\text { 12. I choose to work in hospitality industry because of my family } \\
\text { business. }\end{array}$ & & .627 & & & \\
\hline $\begin{array}{l}\text { 17. My parents expect me to choose an occupation that is in line with the } \\
\text { family tradition. }\end{array}$ & & .601 & & & \\
\hline $\begin{array}{l}\text { 16. I took career or psychological tests that told me hospitality jobs fitted } \\
\text { me. }\end{array}$ & & .554 & & & \\
\hline 20. People in hospitality industry influence me to choose hospitality jobs. & & .550 & & & \\
\hline $\begin{array}{l}\text { 2. My parents only support the decision about my future career that they } \\
\text { want me to pursue. }\end{array}$ & & & .798 & & \\
\hline $\begin{array}{l}\text { 3. My parents always force me to follow their career choice they made } \\
\text { for me. }\end{array}$ & & & .701 & & \\
\hline $\begin{array}{l}\text { 18. My parents only provide me information on the career they want me } \\
\text { to pursue. }\end{array}$ & & & .578 & & \\
\hline $\begin{array}{l}\text { 7. When I make career choice, I asked instructors who had much } \\
\text { hospitality industry experience more than those who did not have. }\end{array}$ & & & & .696 & \\
\hline $\begin{array}{l}\text { 6. College teachers and counselors had the greatest influence in my } \\
\text { career choice. }\end{array}$ & & & & .682 & \\
\hline $\begin{array}{l}\text { 9. My teachers and counselors told me what positions I would pursue in } \\
\text { hospitality industry. }\end{array}$ & & & & .644 & \\
\hline 11. I often discuss my career choice with my classmates. & & & & & .647 \\
\hline $\begin{array}{l}\text { 31. My present or former colleagues give me some advice on future } \\
\text { choice in hospitality industry. }\end{array}$ & & & & & .565 \\
\hline 15. I had some experience in hospitality indu & & & & & .539 \\
\hline
\end{tabular}

Note. Extraction Method: Principal Component Analysis.

Rotation Method: Varimax with Kaiser Normalization.

a. Rotation converged in 6 iterations.

\section{DISCUSSION}


INDEPENDENT JOURNAL OF MANAGEMENT \& PRODUCTION (IJM\&P)

http://www.ijmp.jor.br

v. 8, n. 3, July - September 2017

ISSN: 2236-269X

DOI: 10.14807/ijmp.v8i3.618

Generally, this study confirmed that Super's Life-span, Life-space Theory and Social Cognitive Career Theory were appropriate to inform this study. The findings were also consistent with the knowledge gleaned from the authors' experience in both academic institutions and the professional field in the hotel industry. The influencing factors extracted from the data notably matched the key constructs in the above two underpinning theories.

\subsection{Gender and Grade Difference}

First, this study revealed no statistically significant differences existed between male and female students with reference to what they thought important in determining their career decision except for a few items. These findings were not consistent with the conclusions suggested by some researchers who reported a significant difference between different gender (ZAHARI, 2004; WONG; LIU, 2010). Even, with regard to family influence, the findings did not seem to corroborate the traditional thinking that females were usually more likely to accept parents' opinions and follow parents' ideas than were males (WONG; LIU, 2010).

With reference to different grades, it was found there indeed existed a difference between freshman and sophomore students in multiple items. As noted above, first-year students rated as higher, the influence of teachers and counselors in their career choice and were prone to feel the hospitality jobs more challenging and interesting. This may seem justifiable given second-year students were exposed more to the hospitality industry. With more experience in relationship with industry, sophomore students tended to ask their industry colleagues for help rather than their school teachers. And equally, with more familiarity with the real working circumstance, this group often thought hospitality jobs somewhat monotonous and backbreaking.

The above findings about student gender and grade differences were in line with Super's (1990) claim that gender has little influence in determining students' career choice; what matters is career salience which plays a significant role in career maturity. According to Niles and Harris-Bowlsbey (2005), career maturity is developed in response to the changing vocational opportunities and evolving patterns of life-role participation, and would be accomplished successfully through age and stage developmental tasks across the life span. Factors such as time 
perspective, exploration, information, decision-making, and reality orientation are regarded as underlying the concepts of career maturity and career adaptability (HERR, 1997).

When students first matriculate into college, their career landscapes are foggy and most of the time they choose future career out of curiosity. The most important determinants of future career choice are limited to people around them, such as parents, fellow students, teachers, and friends. As they progress to become sophomores in their career choice journey, they have multiple opportunities to expose themselves to real hospitality context. Although still struggling to explore the future career possibilities, they become more career-mature and career-adaptable. Therefore, hospitality major students make their career decision differently.

\subsection{Influencing Factors}

There are many social, cultural, and psychological factors that may contribute to the career choices of hotel students in Guangzhou. However, the current study revealed five underlying contributory factors. "Students self-efficacy and occupational aspiration" was the most important factor to influence the students' career decision, followed by "tradition and cultural value", "career guidance", "support from parents", and "external consultation".

As mentioned before, these five extracted influencing factors notably match the main constructs in Super's Life-span, Life-space Theory and Social Cognitive Career Theory. The following sections would be devoted to discussing these five factors, although, the order and contents presented might not necessarily be that listed above.

\subsubsection{Cultural Value}

While a large body of literature suggests people make career choices based on their cultural value, this study revealed that tradition and cultural value were eclipsing their importance in influencing students' decision of future occupation. Most respondents did not concur with the statement "I chose hospitality major because of traditional values" (mean= 2.42).

There are two possible reasons. One may be that college students in Guangzhou are millennials who hold different values than other generations. However, it was worthwhile to note the standard deviation for this item was relatively 
INDEPENDENT JOURNAL OF MANAGEMENT \& PRODUCTION (IJM\&P)

http://www.ijmp.jor.br

V. 8, n. 3, July - September 2017

ISSN: 2236-269X

DOI: 10.14807/ijmp.v8i3.618

high (0.89), meaning quite a few students thought their career choice was still affected by tradition culture mostly relating to collectivism, deference towards the elders, and family piety (KIM; ATKINSON; UMEMOTO, 2001).

Another possible reason might be due to distinct Lingnan culture, Cantonese language, and geographical location. Students in Guangzhou embrace different values and characteristics than other parts of China, which will most likely implicitly affect their career choice. Conventionally, Lingnan culture is characterized by openness, assertiveness andentrepreneurship, which fosters the atmosphere of starting and running one's own businesses instead of working for others.

People see this as evidence of career success when parents pass on their businesses to their children (WONG, 2005). As a result, there should be no surprise for HTM graduates in Guangzhou that, after gaining a certain amount of hotel or tourism experience by working for a short period of time in the industry, they can usually be seen establishing their own businesses, no matter small or large. This example also shows the importance of family influence in career decision of HTM students mentioned below.

\subsubsection{Family}

Another traditional value, which is generally considered to exert a powerful influence on the Chinese family, is filial piety which awards parents with absolute authority to bring up their children exactly according to their dictates (WONG, 2007). It seemed justifiable to conclude that HTM graduates in Guangzhou may show their willingness to turn to their parents for advice, especially when they face career dilemmas. Indeed, the results in Table 1 indicated that respecting family members' wishes when making career decision ranked sixth among the most important factors (mean=3.47).

Nevertheless, people should be circumspect when making the above conclusion. As aforementioned, students in Guangzhou may be different from their counterparts in other parts of China. In addition, the student viewpoint on career choice changes with the times. It was clearly shown that although "My family always supports my career decision in working in hospitality industry" (mean= 3.65), most of the students do not choose an occupation in line with their family tradition.

Family can no longer force them to follow a career choice their family made 
INDEPENDENT JOURNAL OF MANAGEMENT \& PRODUCTION (IJM\&P)

http://www.ijmp.jor.br

V. 8, n. 3, July - September 2017

ISSN: 2236-269X

DOI: 10.14807/ijmp.v8i3.618

for them. These, again, contradicted the findings of most scholars who revealed that parents were clearly influential in young people's career choice (FERREIRA; SANTOS; FONSECA; HAASE, 2006; STAMBLER, 1998; WHISTON; KELLER, 2004).

A possible reason may be that although students in Guangzhou asked their parents for initial tuition and fees for attending college, there were ample opportunities for them to find part-time jobs to earn money, which greatly alleviated their parents' burden to support their education. As they became more independent and mature, students would ultimately tend to make their own career choice accordingly.

\subsubsection{School Activity and Career Guidance}

Naturally, school activity encompasses any career-related activities in which students participate during their college education, including student internship, job shadowing, seeking career guidance, meeting with industry leaders and mentors, and any other career exposure that would enhance the students' understanding of industry, work ethic, career required skills, and responsibilities of the job.

It may seem reasonable to hypothesize that early exposure to the industry would affect career decision-making process of HTM students in Guangzhou, regardless of being positively or negatively correlated. The study clearly indicated that respondents tended to think their internship and part-time jobs help them better understand the hospitality industry and influence their career choice, and additionally, they would ask industry-background instructors for help when making a career decision. Further, they often discuss their career choice with classmates and used career reference books to know more about themselves and the hospitality industry.

However, paradoxically it was also observed from the researchers' studentcounseling experience, after a one-year internship, some students would like to apply for a position elsewhere. Hospitality jobs are perceived as monotonous, tedious, and dreary. This observation was confirmed by the results of the T-test for grade category, showing there existed a statistically significant difference between two grade students in items "I find hospitality jobs interesting and challenging" $(t=4.64, p=0.000)$. 
DOI: 10.14807/ijmp.v8i3.618

\subsubsection{Student Self-efficacy}

As discussed previously, self- efficacy is defined as "people's judgments of their capabilities to organize and execute courses of action required to attain designated types of performances" (BANDURA, 1986, p. 391). For HTM students, self-efficacy functions as a mediator to stimulate them up the career ladder to achieve their ultimate goals (FELTZ; PAYMENT, 2005).

For their parts, the confidence in their career-related capability can be increased through successful internship experiences or encouragement from industry managers and co-workers, which in turn, can serve as an effective motivator for them to reinforce the intentions to stay in their chosen career (BANDURA, 1986). This research confirmed students with high level of self-efficacy may be more likely to pursue a hospitality career, which would contribute to stronger career intentions to the industry (CHUANG; DELLMANN-JENKINS, 2010).

Most of them thought that "working in the hospitality industry can help me fulfill my self-actualization" (mean=3.36) and "I think that I have the abilities to work well in hospitality and climb up to higher position" (3.24).

However, it is worth noting students with high self-efficacy in their future hotel related career during their school time turn out to suffer most when they go through an internship or after finishing this required stage. It is perceived in the real industry environment, there seems little, if not no, space for them to climb up along the hotel career ladder.

Additionally, a stark contrast exists between what they expect and what the hotel work actually is. Undoubtedly, both of these perceptions would dampen HTM students' interests in staying in the hotel industry. Under such a circumstance, given the robust economic momentum in Guangzhou, it is suggested students should be encouraged to apply for higher positions at other newly built hotels after certain years' experiences.

Notwithstanding, it could not be denied that there are many HTM students who aspire to work in hotels and their ultimate goals are to assume more responsibility in administrative positions, which requires us to discuss the role that student occupational aspiration plays in career decision making.

\subsubsection{Student Occupational Aspiration}


INDEPENDENT JOURNAL OF MANAGEMENT \& PRODUCTION (IJM\&P)

http://www.ijmp.jor.br

v. 8, n. 3, July - September 2017

ISSN: 2236-269X

DOI: 10.14807/ijmp.v8i3.618

Like self-efficacy, occupational aspiration embraced by HTM students constitutes a crucial element of their motivational structure and might offer invaluable insights into the career decision-making. Indeed, the results of this study revealed most of the students agreed with the statement "I aspire to become a manager in hospitality industry five to ten years after graduation" (mean=3.59). Actually, occupational aspirations have been regarded as significant determinants of longterm career choices (HOLLAND; GOTTFREDSON; BAKER, 1990; SCHOON; PARSONS, 2002).

Additionally, it has been found that students with lower occupational aspirations tend to severely constrain their future career opportunities (ROJEWSKI; HILL, 1998). Furthermore, Patton and Creed (2007) suggest students who reported to aspire to professional status occupations are more likely to achieve their professional goals.

The researchers' previous in-depth conversations and observations with the students revealed students aspiring to high-level management in the hotel industry had staunch determinations to overcome any roadblock they would face in the future careers and are most likely to stick to their aspirations to achieve personal goals.

Yet interestingly, no salient discrepancy can be observed between gender occupational aspirations, although there was evidence to show the present female and male ratio was 8:2 in Hospitality and Tourism College sampled. Furthermore, both female and male proclaimed their ambitions were higher level administrative and managerial positions, such as heads of department, directors, and general managers as their ultimate goals, yet showed little interest in low-echelon jobs.

To conclude, the issue of factors undergirding student career choice has drawn much attention among scholars, educators, industries, and many other interested groups. It was cogently argued there are a rather multitude of intrinsic and extrinsic factors influencing students' career decision-making process. However, it is impossible to give a comprehensive enumeration of all possible constructs, only some major contributing factors have been examined. They are cultural values, familial background, school activity and career guidance, student self-efficacy, as well as student occupational aspiration.

\section{LIMITATIONS}


INDEPENDENT JOURNAL OF MANAGEMENT \& PRODUCTION (IJM\&P)

http://www.ijmp.jor.br

V. 8, n. 3, July - September 2017

ISSN: 2236-269X

DOI: 10.14807/ijmp.v8i3.618

It should be noted some limitations exist in this study. First, although it was considered that a sample of 372 respondents in a single college represented the whole profile of hospitality management students in Guangzhou, one should be cautious about its generalizability to other higher institutions or other cities, and by extension, the whole of China. As was noted previously, the tradition and culture in Guangzhou are largely distinct from other parts of China.

Second, the data were restricted to those collected from the first and secondyear students, junior students were not included in this study. Thus, it was uncertain whether there was any difference between this internship out-school group and inschool students. Moreover, this study would gain more benefits and insights if a longitudinal study and other sampling methods could be embraced. Further, in this study, some participants provided unusable responses.

Therefore, specific procedures should have been implemented to handle the nonresponse errors (DOOLEY; LINDNER, 2003). Lastly, although we computed the Cronbach's Alpha coefficient and the Kaiser-Meyer-Olkin measures of sample adequacy for the instrument prior to further analysis, we did not test the validity of the measurement such as content validity, criteria-related validity, and construct validity.

Future studies should take longitudinal study, test of validity, other sampling techniques into consideration to gain more insights into college students' career choice. Also, due to distinct language and culture, a comparison between Guangzhou and other cities' student perceptions of importance of influencing factors in terms of their career choice intention might be another interesting topic for future study.

\section{SUGGESTIONS AND RECOMMENDATIONS}

From the discussion above, the following suggestions and recommendations are provided which might be beneficial for both HTM institutions and the hotel industry as a whole in Guangzhou, and most probably some might be applicable to other HTM institutions in other parts of China.

First and foremost, when it comes to considering factors influencing HTM students' career choice, it is helpful for us to hold a systems perspective to take into consideration all stakeholders, including students, parents, hotel industry, schools, 
INDEPENDENT JOURNAL OF MANAGEMENT \& PRODUCTION (IJM\&P)

http://www.ijmp.jor.br

v. 8, n. 3, July - September 2017

ISSN: 2236-269X

DOI: 10.14807/ijmp.v8i3.618

and many other social environmental entities. Predicated on this holistic logic, it would be postulated that it is critical to continue to build firm and stable ties between HTM schools and hotel companies.

Fortunately, this practice has been enforced and enacted by governments to encourage the work-to-study project. HTM schools and hotel companies are directed to form strategic bonds which would allow them to cooperate on student matriculation, curriculum development, career counseling, internship and externship, and teacher selection.

Secondly, it is nationally recognized that students facing career choice would benefit from the advice and suggestions given by instructors with hotel-working experience. For this reason, employing a certain percentage of teachers from industry would constitute the competitive edge for educational institutions to attract more students in HTM program. Moreover, HTM schools should host more careerrelated activities for students to be exposed to real industry environments. In this way, students could enhance their understanding of industry, work ethic, career required skills, and responsibilities of hotel jobs.

The third recommendation we would make is that HTM schools, students, and hotels sign an agreement to ensure all parties involved both assume responsibilities and enjoy benefits from this triadic relationship. In this way, students may seamlessly and smoothly move into hotel profession to promote their professional advancement and career aspirations, while schools accomplish their mission of cultivating and nurturing the most capable students to meet the requirements of the industry.

Simultaneously, hotels could easily obtain a stable and secure repository of qualified employees. Moreover, hotels and HTM schools could help students by means of offering scholarships, grants, financial assistance, and even tuition waiver, which could further galvanize students' interest in joining the HTM program.

Lastly, it is imperative for HTM managers to create welcoming working climates and cultures and harmonious interpersonal relations to alleviate the degree of work dullness, burn-out, and pressure existing in hotel positions. Furthermore, it is recommended that compensation packages be periodically surveyed, so the school graduates could maintain high self-efficacy to perform their job and feel the hospitality industry can help them fulfill their self-actualization. Additionally, it is 
suggested the hotels develop and provide clear career paths for their employees in order for them to hone their management skills to advance their careers.

\section{CONCLUSION}

In this paper, we examined the students' perceptions of importance with reference to influencing factors of their career options in the Hospitality Department of a polytechnic college in Guangzhou City, China. This study makes significant theoretical and practical contributions to hospitality major students' career choice in Guangzhou City.

First, we surprisingly found more students made their own career choice with less influence from traditional values and their family members. Additionally, the results of this study clearly showed there was no statistically significant difference between male and female students; however, a difference between freshmen and sophomore respondents was found for some items.

Further, this study identified five underlying contributory factors influencing students' career choice. "Students self-efficacy and occupational aspiration" was the most important factor to influence the students' career decision, followed by "tradition and cultural value", "career guidance", "support from parents", and "external consultation".

Finally, the suggestions and recommendations we made provide a guideline for both hospitality educators and practitioners to follow. The ultimate goal is to help hospitality industry to attract and retain qualified HTM graduates, thus assisting hospitality educators and practitioners to address some pressing human resource challenges.

\section{REFERENCES}

BANDURA, A. (1986). Social foundations of thought and action: A social cognitive theory. Upper Saddle River, NJ: Prentice Hall.

BORCHERT, M. (2002). Career choices of high school students (Unpublished master's thesis). University of Wisconsin-Stout, Menomonie, WI.

BUI, U. (2005). The career development of Vietnamese Americans: Factors in career self-efficacy and traditionality of career choice (Unpublished doctoral dissertation), University of California, Santa Barbara, CA.

CHINA INBOUND TOURISM IN 2015. (n.d.). Retrieved September 2, 2016, from: 
INDEPENDENT JOURNAL OF MANAGEMENT \& PRODUCTION (IJM\&P)

http://www.ijmp.jor.br

v. 8, n. 3, July - September 2017

ISSN: 2236-269X

DOI: 10.14807/ijmp.v8i3.618

https://www.travelchinaguide.com/tourism/2015statistics/inbound.htm

CHINA TOURISM FACTS \& FIGURES 2014. (n. d.). Retrieved November 2, 2016, from: https://www.travelchinaguide.com/tourism/2014statistics/.

CHUANG, N. K.; DELLMANN-JENKINS, M. (2010). Career decision making and intention: A study of hospitality undergraduate students. Journal of Hospitality \& Tourism Research, v.34, n. 4, p. 512-530. doi: 10.1177/1096348010370867

DOOLEY, L. M.; LINDNER, J. R. (2003), The handling of nonresponse error. Human Resource Development Quarterly, v.14, p. 99-110. doi:10.1002/hrdq.1052

FERREIRA, J. A.; SANTOS, E. J. R.; FONSECA, A. C.; HAASE, R. F. (2006). Early predictors of career development: a ten-year follow-up study, Journal of Vocational Behavior, v. 70, p. 61-77.

FELTZ, D. L.; PAYMENT, C. A. (2005). Self-efficacy beliefs related to movement and mobility. Quest, v. 57, p. 24-36.

HERR, E. L. (1997). Super's life-span, life-space approach and its outlook for refinement. The Career Development Quarterly, v. 45, p. 238-245.

HOLLAND, J. L.; GOTTFREDSON, L. S.; BAKER, H. G. (1990). Validity of vocational aspirations and interest inventories: Extended, replicated, and reinterpreted. Journal of Counseling Psychology, v. 37, p. 337-342.

KIM, B. S. K.; ATKINSON, D. R.; UMEMOTO, D. (2001). Asian cultural values and the counseling process: Current knowledge and directions for future research. The Counseling Psychologist, v. 29, n. 4, p. 570-563.

LENT, R. W. (2005). A social cognitive view of career development and counseling. In S. D. Brown \& R. T. Lent (Eds.), Career development and counseling: Putting theory and research to work (p. 101-127). Hoboken, NJ: Wiley.

LENT, R. W.; BROWN, S. D.; HACKETT, G. (2000). Contextual supports and barriers to career choice: a social cognitive analysis. Journal of Counseling Psychology, v. 47, p. 36-49. doi: 10.1037//0022-0167.47.1.36

LENT, R. W.; BROWN, S. D.; HACKETT, G. (2002). Social cognitive career theory. In D. Brown \& Associate (Eds.), Career choice and development (4th ed., p. 255311).San Francisco, CA: Jossey-Bass.

LEUNG, S. A. (2008). The big-five career theories. In J. A., Athanasou, \& R. V., Esbroeck (Ed.), International handbook of career guidance (p.115-132). New York, NY: Springer.

NILES, S. G.; HARRIS-BOWLSBEY, J. (2005). Career development interventions in the 21st century (2nd ed.). Upper Saddle River, NJ: Merrill Prentice Hall.

NUNNALLY, J. C. (1978). Psychometric theory. New York, NY: McGraw-Hill.

PATTON, W. A.; CREED, P. (2007). Occupational aspirations and expectations of Australian adolescents. Australian Journal of Career Development, v. 16, n. 1, p. 46-59.

ROJEWSKI, J. W.; HILL, R. B. (1998). Influence of gender and academic risk behavior on career decision making and occupational choice in early adolescence. Journal of Education for Students Placed at Risk, v. 3, p. 265-287.

SAVICKAS, M. L. (2002). Career construction: A developmental theory of vocational 
INDEPENDENT JOURNAL OF MANAGEMENT \& PRODUCTION (IJM\&P)

http://www.ijmp.jor.br

v. 8, n. 3, July - September 2017

ISSN: 2236-269X

DOI: 10.14807/ijmp.v8i3.618

behavior. In D. Brown \& Associate (Eds.), Career choice and development (4th ed., p. 149-205). San Francisco, CA: Jossey-Bass.

SCHOON, I.; PARSONS, S. (2002). Teenage aspirations for future careers and occupational outcomes. Journal of Vocational Behavior, v. 60, p. 262-288. doi:10.1006/jvbe.2001.1867

STAMBLER, B. J. (1998). An examination of the effects of parental influence on secondary school completion (Unpublished Ed D dissertation), State University of New York at Albany, Albany, NY.

SUPER, D. E. (1963). Self-concepts in vocational development. In D. E. Su J. P. Jordaan, (Eds.), Career development: Self-concept theory (p. 17-32). New York: College Entrance Examination Board.

SUPER, D. E. (1990). A Life-Span, Life-Space Approach to Career Development in D. Brown, L. Brooks, \& Associates (Eds). Career choice and development:

Applying contemporary theories to practice (2nd ed., p. 197-261). San Francisco: Jossey-Bass.

SUPER, D. E.; SAVICKAS, M. L.; SUPER, C. M. (1996) A Life-Span, Life-Space Approach to Career Development in D. Brown, L. Brooks, \& Associates (Eds). Career choice and development: Applying contemporary theories to practice (3rd ed., p. 121-178). San Francisco: Jossey-Bass.

TAY, K. H. (1996). Factors influencing career choice of selected Chinesedescendant international students: A cross-national validity study of Holland's theory of vocational personalities and work environments (Unpublished doctoral dissertation). Georgia State University, Atlanta, GA.

WHISTON, S. C.; KELLER, B.K. (2004). The influences of the family of origin on career development: A review and analysis. The Counseling Psychologist, v. 32, n. 4, p. 493-568. doi: 10.1177/0011000004265660

WOLFINGTON, V. A.; WOLFINGTON, M. A. (2012). The hospitality talent gap. Retrieved November 28, 2016 from http://www.chinabusinessreview.com/thehospitality-talent-gap/.

WONG, A. L. Y. (2007). Making career choice: A study of Chinese managers. Human Relations, v. 60, n. 8, p.1211-1233. doi: 10.1177/0018726707081661

WONG, A. L. Y. (2005). Type A behaviour at work: An empirical study of Taiwanese managers and entrepreneurs. International Journal of Human Resource Management, v. 16, n. 11, p. 2147-2160. doi: 10.1080/09585190500315166

WONG, S. C.; LIU, G. J. (2010). Will parental influences affect career choice? Evidence from hospitality and tourism management students in China. International Journal of Contemporary Hospitality Management, v. 22, n. 1, p. 82-102. doi:10.1108/09596110110365599

ZAHARI, M. S. M. (2004). A study of factors moderating Malaysian hospitality students' selection of tertiary education institutions, programme and subsequent career intentions (Unpublished doctoral dissertation). Lincoln University, Christchurch, New Zealand.

ZHAO, Y. (2015, October 14). Five-star hotel occupancy in Guangzhou. Yangcheng Daily, p. A17. 
ISSN: 2236-269X

DOI: 10.14807/ijmp.v8i3.618 